\title{
Human Eosinophil Major Basic Protein Is an Endogenous Allosteric Antagonist at the Inhibitory Muscarinic M2 Receptor
}

\author{
David B. Jacoby, ${ }^{*}$ Gerald J. Gleich, ${ }^{\star}$ and Allison D. Fryer \\ *Division of Pulmonary and Critical Care Medicine, Johns Hopkins Asthma and Allergy Center, Baltimore, Maryland 21224; \\ ${ }^{\ddagger}$ Departments of Immunology and Medicine, Mayo Clinic, Rochester, Minnesota 55905; and ${ }^{\S}$ Department of Environmental Health \\ Sciences, Johns Hopkins School of Hygiene and Public Health, Baltimore, Maryland 21205
}

\begin{abstract}
The effect of human eosinophil major basic protein (MBP), as well as other eosinophil proteins, on binding of $\left[{ }^{3} \mathrm{H}\right] \mathrm{N}$-methylscopolamine $\left(\left[{ }^{3} \mathrm{H}\right] \mathrm{NMS} ; 1 \times 10^{-10} \mathrm{M}\right)$ to muscarinic M2 receptors in heart membranes and $\mathrm{M3}$ receptors in submandibular gland membranes was studied. MBP inhibited specific binding of $\left[{ }^{3} \mathrm{H}\right] \mathrm{NMS}$ to $\mathrm{M} 2$ receptors but not to $\mathrm{M3}$ receptors. MBP also inhibited atropine-induced dissociation of $\left[{ }^{3} \mathbf{H}\right]-$ NMS-receptor complexes in a dose-dependent fashion, demonstrating that the interaction of MBP with the M2 muscarinic receptor is allosteric. This effect of MBP suggests that it may function as an endogenous allosteric inhibitor of agonist binding to the $\mathrm{M} 2$ muscarinic receptor. Inhibition of $\left[{ }^{3} \mathrm{H}\right] \mathrm{NMS}$ binding by MBP was reversible by treatment with heparin, which binds and neutralizes MBP. Eosinophil peroxidase (EPO) also inhibited specific binding of $\left[{ }^{3} \mathrm{H}\right] \mathrm{NMS}$ to $\mathrm{M} 2$ receptors but not to $M 3$ receptors and inhibited atropine-induced dissociation of $\left[{ }^{3} \mathrm{H}\right] \mathrm{NMS}-$-receptor complexes. On a molar basis, EPO is less potent than MBP. Neither eosinophil cationic protein nor eosinophil-derived neurotoxin affected binding of $\left.{ }^{3} \mathrm{H}\right] \mathrm{NMS}$ to $\mathrm{M2}$ receptors. Thus both $\mathrm{MBP}$ and EPO are selective allosteric antagonists at $M 2$ receptors. The effects of these proteins may be important causes of $\mathrm{M} 2$ receptor dysfunction and enhanced vagally mediated bronchoconstriction in asthma. (J. Clin. Invest. 1993. 91:1314-1318.) Key words: asthma $\bullet$ airways $\bullet$ heparin $\bullet$ pulmonary $\bullet$ parasympathetic nervous system
\end{abstract}

\section{Introduction}

The lungs contain multiple subtypes of muscarinic receptors $(1,2)$. Acetylcholine release from the pulmonary parasympathetic nerves stimulates muscarinic M3 receptors on smooth muscle, contracting the muscles and causing bronchoconstriction (3). At the same time, release of acetylcholine from the parasympathetic nerves is limited by inhibitory muscarinic M2

Some of these data have been presented as an abstract (1992. Am. Rev. Respir. Dis. 145:A436).

Address correspondence to Dr. David B. Jacoby, Johns Hopkins Asthma and Allergy Center, 5501 Hopkins Bayview Circle, Baltimore, MD 21224. 1992.

Received for publication 6 July 1992 and in revised form 26 October

J. Clin. Invest.

(c) The American Society for Clinical Investigation, Inc.

$0021-9738 / 93 / 04 / 1314 / 05 \quad \$ 2.00$

Volume 91, April 1993, 1314-1318 receptors on the nerve endings (Fig. 1) (4). Such inhibitory neuronal receptors have been demonstrated in guinea pigs (4), cats (5), dogs (6), and humans (7).

Blocking the neuronal M2 muscarinic receptor using selective antagonists eliminates the normal negative feedback and increases the release of acetylcholine. This results in an 8-10fold increase in the bronchoconstriction caused by electrical stimulation of the vagus nerves (4). Conversely, when pilocarpine is used to stimulate the $M 2$ receptors, the response to subsequent vagal stimulation is reduced by $80 \%$ (4).

Inhibitory M2 receptors do not function normally in the airways of asthmatics $(8,9)$ or in antigen-challenged guinea pigs $(10,11)$. Loss of negative feedback in these conditions is probably an important cause of increased vagally mediated bronchoconstriction.

In asthmatics (12-15) and after antigen challenge (16, 17), the airways are infiltrated with eosinophils, which contain three strongly positively charged proteins: major basic protein ( $\left.\mathrm{MBP} ;{ }^{1} \mathrm{pI}=10.9\right)$, eosinophil peroxidase (EPO; pI = 10.8), and eosinophil cationic protein (ECP; $\mathrm{pI}=10.8)$, as well as the less strongly charged eosinophil-derived neurotoxin $(\mathrm{pI}=8.9)$ $(18,19)$. Recent studies have shown that several positively charged proteins, including protamine, poly- $l$-arginine, and poly- $l$-lysine, are $M 2$ receptor antagonists (20). Therefore, it is possible that in the face of eosinophilic infiltration of the airways, one or more of these positively charged proteins acts as an endogenous antagonist at the M2 receptor, thereby eliminating the negative feedback control of acetylcholine release and potentiating vagally mediated bronchoconstriction.

We have recently shown that the strongly negatively charged substances heparin and poly-l-glutamic acid both restore the function of $\mathrm{M} 2$ receptors in vivo in antigen-challenged guinea pigs (11). This effect may result from binding positively charged proteins such as MBP, EPO, or ECP, and displacing them from the neuronal M2 receptors. In this study, we used in vitro ligand-receptor binding studies to further investigate the role of human MBP (and other human eosinophil proteins) in the loss of muscarinic $\mathrm{M} 2$ receptor function.

The multiple muscarinic receptor subtypes present in the lung $(1,2,21)$ would make it difficult to use lung membranes to determine the selective effects of these proteins. Therefore, we used guinea pig heart membranes, which contain a homogeneous population of M2 muscarinic receptors $(22,23)$, and guinea pig submandibular gland membranes, which contain a homogeneous population of M3 muscarinic receptors (21, $24,25)$.

1. Abbreviations used in this paper: $\mathrm{ECP}$, eosinophil cationic protein; EPO, eosinophil peroxidase; MBP, major basic protein; NMS, $N$-methylscopolamine. 


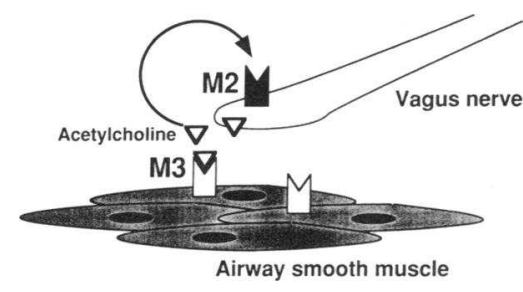

Figure 1. In the airways, release of acetylcholine from the vagus nerve contracts smooth muscle by stimulating muscarinic $\mathrm{M} 3$ receptors. At the same time, the acetylcholine feeds back onto inhibitory muscarinic $\mathrm{M} 2$ receptors on the nerve endings, and thereby limits further release of acetylcholine.

\section{Methods}

Tissue preparation. Guinea pigs (Dunkin-Hartley, 250-400 g; Charles River Breeding Laboratories, Wilmington, MA) were killed by asphyxiation with $\mathrm{CO}_{2}$. The heart and parotid glands were quickly removed and rinsed with $50 \mathrm{mM} \mathrm{Na}^{+} / \mathrm{K}^{+}$phosphate buffer, $\mathrm{pH}$ 7.4. The tissues were blotted dry, weighed, and homogenized using a Polytron (setting 7, $30 \mathrm{~s}$; Brinkmann Instruments, Inc., Westbury, NY). Homogenates were centrifuged for $10 \mathrm{~min}$ at $1,000 \mathrm{~g}$ at $4^{\circ} \mathrm{C}$, and the supernatants were then centrifuged for $30 \mathrm{~min}$ at $30,000 \mathrm{~g}$ at $4^{\circ} \mathrm{C}$. The final pellet was suspended in buffer to give whole organ weight/buffer volume working solutions of $14 \%$. Tissue homogenates were stored in aliquots at $-80^{\circ} \mathrm{C}$. Protein concentrations of the homogenates were determined with the Bio-Rad Protein Assay Kit (Bio-Rad Laboratories, Richmond, CA), using bovine serum albumin as a standard.

Isolation of human eosinophil granule proteins. Eosinophil proteins were isolated as described previously $(18,26,27)$. Briefly, granules isolated from human eosinophils were dissolved in $10 \mathrm{mM}$ hydrochloric acid, and the proteins were separated by Sephadex G-50 gel filtration to yield MBP, followed by heparin-Sepharose chromatography to yield ECP and eosinophil-derived neurotoxin, and by carboxymethylSepharose chromatography to yield EPO.

Receptor binding assays. Competition binding experiments were done by incubating guinea pig heart and submandibular gland membranes $(0.5-1.0 \mathrm{mg}$ protein $/ \mathrm{ml})$ in triplicate with $\left[{ }^{3} \mathrm{H}\right] \mathrm{N}$-methylscopolamine $\left(\left[{ }^{3} \mathrm{H}\right] \mathrm{NMS}, 1 \times 10^{-10} \mathrm{M}\right.$; New England Nuclear, Boston, MA) in the absence or presence of $\operatorname{MBP}\left(10^{-7}-3 \times 10^{-5} \mathrm{M}\right), \operatorname{ECP}\left(10^{-7}\right.$ $\left.-3 \times 10^{-5} \mathrm{M}\right)$, EPO $\left(10^{-7}-3 \times 10^{-5} \mathrm{M}\right)$, or eosinophil-derived neurotoxin $\left(10^{-7}-1.5 \times 10^{-5} \mathrm{M}\right)$ in a final reaction volume of $100 \mu \mathrm{l}$. Nonspecific binding (measured in the presence of atropine $\left(2 \times 10^{-6}\right.$ M) was subtracted from total binding to determine specific binding. Samples were incubated at room temperature for $3 \mathrm{~h}$, after which unbound ligand was removed by filtration using a Skatron cell harvester. Filters were dissolved in Biosafe II scintillation fluid (Research Products International, Mount Prospect, IL) and counted on a scintillation counter (Beckmann Instruments, Inc., Fullerton, CA).

The dissociation constant $\left(K_{\mathrm{d}}\right)$ for [ $\left.{ }^{3} \mathrm{H}\right] \mathrm{NMS}$ binding to $\mathrm{M} 2$ receptors was required for calculation of the $K_{\mathrm{d}}$ for MBP from the competition experiments described above. To determine the $K_{d}$ for [ ${ }^{3} \mathrm{H}$ ]NMS, heart membranes were incubated to equilibrium with $\left[{ }^{3} \mathrm{H}\right] \mathrm{NMS}(0.1$, $0.2,0.4,0.6$, and $1.0 \times 10^{-9} \mathrm{M}$ ) in the absence (total binding) or presence (nonspecific binding) of atropine $\left(2 \times 10^{-6} \mathrm{M}\right)$. Samples were handled as above, and the nonspecific binding (which did not exceed $10 \%$ of total binding) was subtracted from the total binding to yield specific binding. Data were analyzed using a Scatchard plot, in which the ratio of specifically bound ligand to free ligand is plotted against specifically bound ligand. This yields a linear relationship in which the slope of the regression line is equal to $-1 / K_{d}(28)$.

To determine the $K_{\mathrm{d}}$ for MBP, the concentration of MBP required to displace $50 \%$ of specifically bound $\left[{ }^{3} \mathrm{H}\right] \mathrm{NMS}$ from guinea pig heart membranes $\left(E D_{s 0}\right)$ was estimated in each of the competition binding experiments. The $K_{\mathrm{d}}$ for MBP binding to the M2 receptor was then determined using the equation (28):

$$
K_{\mathrm{d}}(\mathrm{MBP}) \frac{\mathrm{EC}_{50}}{1+\frac{\left[\left[{ }^{3} \mathrm{H}\right] \mathrm{NMS}\right]}{K_{\mathrm{d}}\left(\left[{ }^{3} \mathrm{H}\right] \mathrm{NMS}\right)}}
$$

Dissociation studies. To determine whether the eosinophil proteins were competitive or allosteric antagonists, we determined the effect of eosinophil proteins on dissociation of ligand from the M2 receptor. The ability to delay the dissociation of ligand from a receptor demonstrates that the interaction of a substance (in this case, an eosinophil protein) with the receptor is allosteric (29-31). Heart membranes were incubated to equilibrium with $0.1 \mathrm{nM}\left[{ }^{3} \mathrm{H}\right] \mathrm{NMS}$. Atropine $\left(2 \times 10^{-6}\right.$ $\mathrm{M})$ was then added in the absence or presence of $\mathrm{MBP}\left(10^{-7}-3 \times 10^{-5}\right.$ $\mathrm{M})$ or $\operatorname{EPO}\left(10^{-7}-10^{-5} \mathrm{M}\right)$ and the reaction mixture was incubated for $5 \mathrm{~min}$ before filtering.

Reversibility of MBP binding. To test whether MBP binds irreversibly to the M2 receptor, heart membranes were incubated with $\left[{ }^{3} \mathrm{H}\right]$ NMS $\left(1 \times 10^{-10} \mathrm{M}\right)$ and $\mathrm{MBP}\left(10^{-5} \mathrm{M}\right)$ for $3 \mathrm{~h}$, as above. Heparin, which binds and precipitates MBP in vitro (32), was then added at a concentration of $100 \mathrm{U} / \mathrm{ml}$, and the mixture was incubated for $3 \mathrm{~h}$ more before filtering. The effects of a wide range of concentrations of heparin $(0.025-100 \mathrm{U} / \mathrm{ml})$ on $\left[{ }^{3} \mathrm{H}\right] \mathrm{NMS}$ binding to $\mathrm{M} 2$ receptors in the absence of MBP were also tested as a control.

\section{Results}

MBP displaced [ ${ }^{3} \mathrm{H}$ ] NMS from guinea pig heart membranes (M2 receptors) in dose-dependent fashion (Fig. 2). At the highest concentration tested $\left(3 \times 10^{-5} \mathrm{M}\right)$, MBP displaced $\sim 60 \%$ of specifically bound ligand. In contrast, MBP did not displace $\left[{ }^{3} \mathrm{H}\right]$ NMS from submandibular gland membranes (M3 receptors; Fig. 3). Thus the effect of MBP is selective for M2, but not M3, muscarinic receptors.

The $K_{\mathrm{d}}$ for $\left[{ }^{3} \mathrm{H}\right] \mathrm{NMS}$ binding to the M2 receptor was 2.2 $\times 10^{-10} \pm 0.84 \times 10^{-11} \mathrm{M}$ (mean $\pm \mathrm{SE}, n=3$ ). Using this value, the $K_{\mathrm{d}}$ for MBP binding to the M2 receptor was calculated to be $1.4 \times 10^{-5} \pm 0.5 \times 10^{-6} M(n=5)$.

In the absence of MBP, atropine $\left(2 \times 10^{-6} \mathrm{M}\right)$ displaced $70 \%$ of specifically bound $\left[{ }^{3} \mathrm{H}\right] \mathrm{NMS}$ from $\mathrm{M} 2$ receptors after 5 min. As shown in Fig. 4, MBP inhibited this dissociation in a concentration-dependent fashion. This demonstrates that the interaction of MBP with the M2 receptor is allosteric.

EPO, which is also strongly positively charged, also displaced $\left[{ }^{3} \mathrm{H}\right]$ NMS from heart membranes but not from submandibular gland membranes (Figs. 5 and 6 ). Higher concentrations of EPO (relative to MBP) are required to displace $\left[{ }^{3} \mathrm{H}\right] \mathrm{NMS}$ from M2 receptors. $\left[{ }^{3} \mathrm{H}\right.$ ]NMS binding was reduced to $71 \pm 4 \%$ control in the presence of $3 \times 10^{-5} \mathrm{M}$ EPO. EPO inhibited dissociation of $\left[{ }^{3} \mathrm{H}\right]$ NMS from $\mathrm{M} 2$ receptors in the presence of atropine (Fig. 7), demonstrating that EPO, too, is an allosteric antagonist at the $\mathrm{M} 2$ receptor.

In contrast, despite being positively charged, ECP at con-

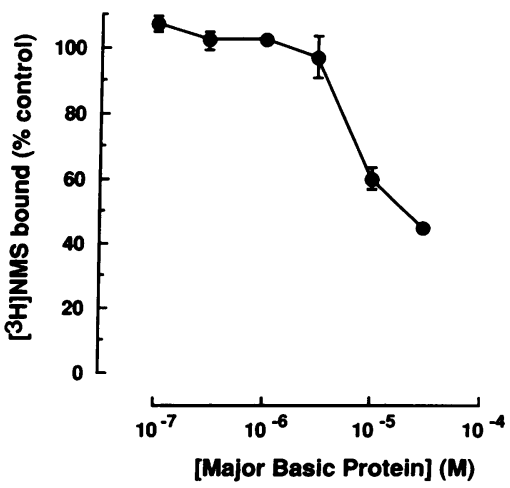

Figure 2. MBP inhibits $\left[{ }^{3} \mathrm{H}\right]$ NMS binding to M2 muscarinic receptors $(n=5 ;$ mean $\pm \mathrm{SE})$. Guinea pig heart membranes were incubated to equilibrium $(3 \mathrm{~h})$ with $\left[{ }^{3} \mathrm{H}\right] \mathrm{NMS}(1$ $\left.\times 10^{-10} \mathrm{M}\right)$ in the absence or presence of various concentrations of MBP. Nonspecific binding of $\left[{ }^{3} \mathrm{H}\right] \mathrm{NMS}$,

determined in the presence of atropine $\left(2 \times 10^{-6} \mathrm{M}\right)$ was subtracted from total binding to yield specifically bound $\left[{ }^{3} \mathrm{H}\right]$ NMS. 


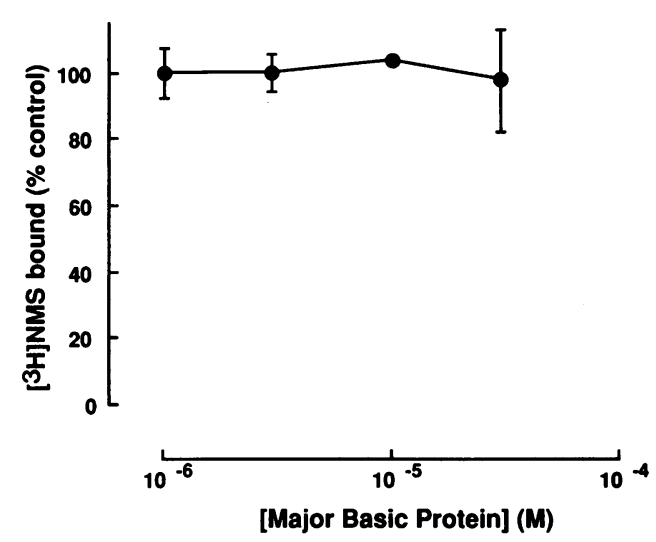

Figure 3. MBP does not affect binding of $\left[{ }^{3} \mathrm{H}\right] \mathrm{NMS}$ to M3 muscarinic receptors $(n=3$; mean $\pm \mathrm{SE})$. The experimental procedure was the same as in Fig. 2 except that guinea pig submandibular gland membranes were used.

centrations as high as $3 \times 10^{-5} \mathrm{M}$ did not displace $\left[{ }^{3} \mathrm{H}\right] \mathrm{NMS}$ from heart membranes (Fig. 8). Eosinophil-derived neurotoxin, which is less strongly cationic, had no effect on $\left[{ }^{3} \mathrm{H}\right] \mathrm{NMS}$ binding to heart membranes at concentrations as high as $1.5 \times 10^{-5} \mathrm{M}$ (the highest concentration tested; data not shown).

The binding of MBP to M2 receptors was completely reversible by treatment with heparin (Fig. 9). In these experiments, incubation of $\left[{ }^{3} \mathrm{H}\right] \mathrm{NMS}$ with heart membranes for $6 \mathrm{~h}$ in the presence of MBP $\left(10^{-5} \mathrm{M}\right)$ resulted in specific binding of $58 \pm 4.3 \%$ control. When heparin $(100 \mathrm{U} / \mathrm{ml})$ was added for the final $3 \mathrm{~h}$ of this incubation, the binding of $\left[{ }^{3} \mathrm{H}\right] \mathrm{NMS}$ was restored to $105.3 \pm 8.9 \%$ control. In control experiments without MBP, $\left[{ }^{3} \mathrm{H}\right]$ NMS binding to M2 receptors was within $20 \%$ of control throughout the range of heparin concentrations tested $(0.025-100 \mathrm{U} / \mathrm{ml})$, and was $85 \%$ of control at $100 \mathrm{U} / \mathrm{ml}$. Thus a direct effect of heparin on $\left[{ }^{3} \mathrm{H}\right]$ NMS binding to M2 receptors cannot explain the effect of heparin on displacement of $\left[{ }^{3} \mathrm{H}\right] \mathrm{NMS}$ by MBP.

\section{Discussion}

These data show that both MBP and EPO bind to muscarinic M2 receptors. In contrast, neither of these proteins affects bind-

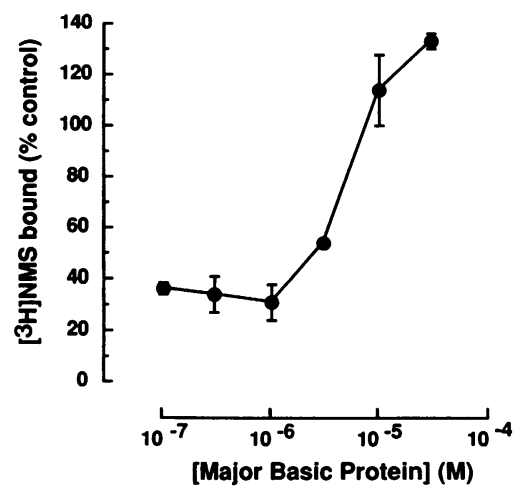

Figure 4. MBP slows dissociation of $\left[{ }^{3} \mathrm{H}\right] \mathrm{NMS}$ from M2 muscarinic receptors in the presence of atropine $\left(2 \times 10^{-6} \mathrm{M} ; n=3\right.$; mean \pm SE). Guinea pig heart membranes were incubated to equilibrium with $\left[{ }^{3} \mathrm{H}\right] \mathrm{NMS}(1$ $\times 10^{-10} \mathrm{M}$ ). Atropine was then added alone or in the presence of various concentrations of MBP. The reaction was stopped by filtration after 5 min.

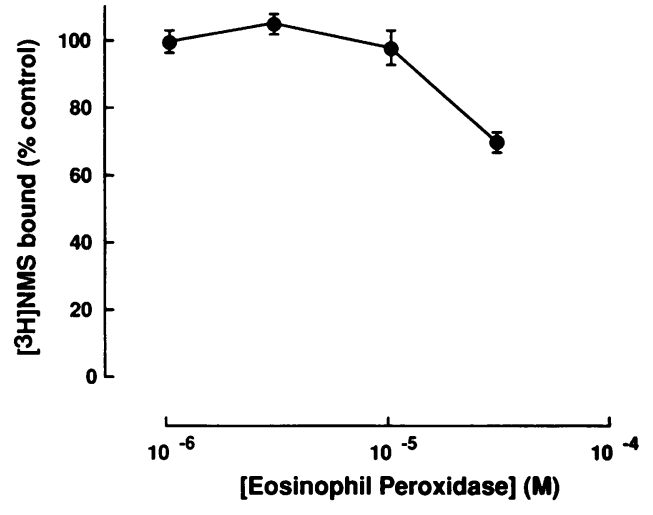

Figure 5. EPO inhibits [ $\left.{ }^{3} \mathrm{H}\right] \mathrm{NMS}$ binding to M2 muscarinic receptors $(n=5$; mean \pm SE). See Fig. 2 for procedure.

ing of $\left[{ }^{3} \mathrm{H}\right]$ NMS to submandibular gland membranes (M3 receptors). As both MBP and EPO are strongly positively charged, this is consistent with the recent demonstration that the cationic peptides poly- $l$-arginine, poly- $l$-lysine, basic histone, and protamine are all antagonists for M2 receptors with no effect on M3 receptors (20).

The ability of both proteins to slow the dissociation of $\left[{ }^{3} \mathrm{H}\right]$ NMS from M2 receptors in the presence of atropine (Figs. 4 and 7 ) demonstrates that they are allosteric antagonists. This is again consistent with the findings of $\mathrm{Hu}$ et al., who showed that the interaction of the cationic peptides poly- $l$-arginine, poly-l-lysine, basic histone, and protamine with the M2 receptor is allosteric (20). The $\left[{ }^{3} \mathrm{H}\right] \mathrm{NMS}$ remaining bound after a 5-min incubation with $\mathrm{MBP}\left(10^{-5}\right.$ and $\left.3 \times 10^{-5} \mathrm{M}\right)$ and atropine was actually greater than that bound in the absence of atropine. This phenomenon, which has been described with other allosteric antagonists (29-31), is not understood.

In addition to positive charge, there must be other structural characteristics that determine whether a protein will act as an M2 receptor antagonist. Despite its strong positive charge, ECP did not displace $\left[{ }^{3} \mathrm{H}\right]$ NMS from heart membranes. This is again consistent with the studies of $\mathrm{Hu}$ et al. (20), who showed that despite their positive charge, putrescine and spermidine were not $\mathbf{M} 2$ receptor antagonists.

It has recently been shown that aspartate residues that are conserved in all muscarinic receptor subtypes, at positions 71

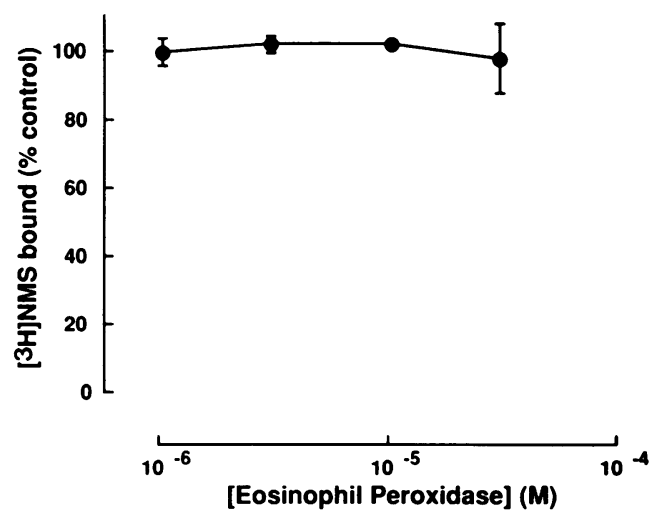

Figure 6. EPO does not affect binding of $\left[{ }^{3} \mathrm{H}\right] \mathrm{NMS}$ to M3 muscarinic receptors $(n=3$; mean $\pm \mathrm{SE})$. See Fig. 3 for procedure. 


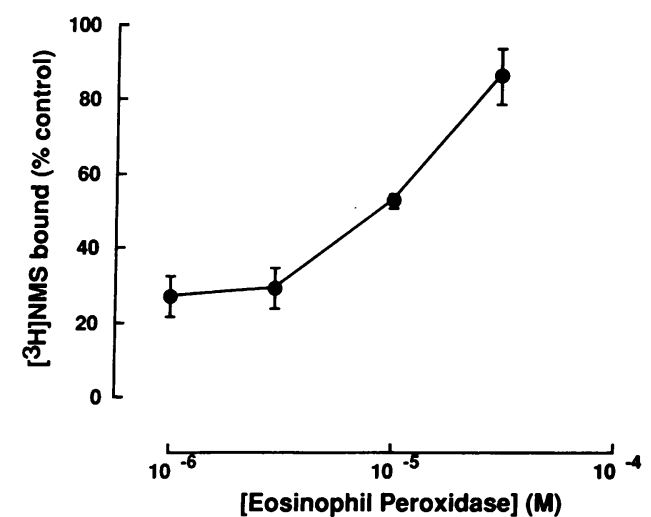

Figure 7. EPO slows dissociation of $\left[{ }^{3} \mathrm{H}\right] \mathrm{NMS}$ from $\mathrm{M} 2$ muscarinic receptors in the presence of atropine $\left(2 \times 10^{-6} \mathrm{M} ; n=3\right.$; mean $\left.\pm \mathrm{SE}\right)$. See Fig. 4 for procedure.

and 99 of the rat $\mathrm{M} 1$ receptor, affect the interaction of gallamine, an allosteric antagonist, with the receptor (33). Mutating these aspartate residues to asparagine altered the affinity of gallamine for the receptor and decreased the maximal effect of gallamine on the binding of $\left[{ }^{3} \mathrm{H}\right] \mathrm{NMS}$ to the receptor. It has been suggested that gallamine's three quaternary amine groups allow it to interact with these negatively charged aspartate residues. Similar interactions may be involved in the interaction of MBP and EPO with the M2 receptor, as not all such proteins in our study or in the study of $\mathrm{Hu}$ et al. (20) were M2 receptor antagonists.

It is not possible on the basis of these data to exclude the possibility that MBP and EPO interact with a receptor-linked $G$ protein. Indeed, it has been reported that guanosine-5'triphosphate and 5'-guanylylimidodiphosphate both increase muscarinic receptor high-affinity binding of the antagonist ligand quinuclidinyl benzilate (34). It is possible that MBP and EPO decrease antagonist ligand binding by interfering with the interaction of endogenous guanosine-5'-triphosphate and $G$ proteins with the receptor. Whether such interactions would explain the inhibition of atropine-induced receptor-ligand dissociation is unknown.

Guinea pigs that are sensitized to ovalbumin and then challenged with an aerosol of ovalbumin become hyperresponsive to electrical stimulation of the vagus $(10,35)$. This hyperresponsiveness is accompanied by, and probably due to, severe dysfunction of inhibitory $\mathbf{M} 2$ receptors on the nerves (10). Because antigen challenge causes pulmonary eosinophilia (16,

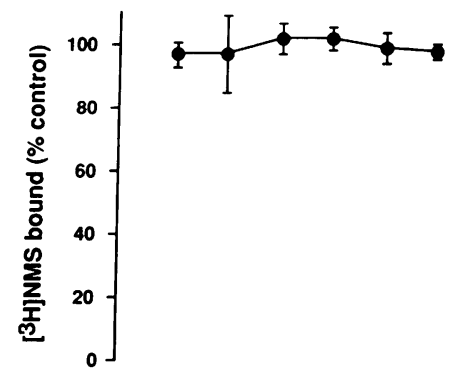

Figure 8. ECP does not affect binding of $\left[{ }^{3} \mathrm{H}\right] \mathrm{NMS}$ to $\mathrm{M} 2$ mus-

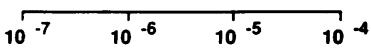

[Eosinophil Cationic Protein] (M)
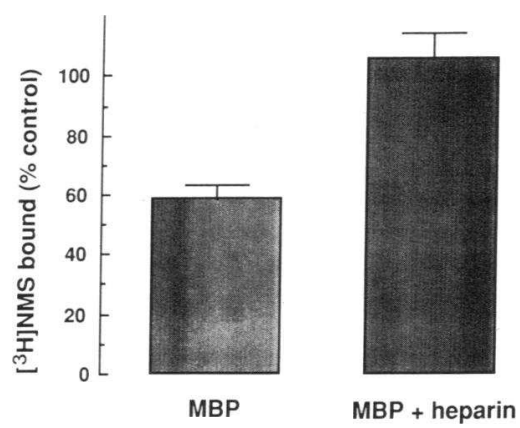

Figure 9. Heparin reverses the inhibition of $\left[{ }^{3} \mathrm{H}\right]$ NMS binding to M2 muscarinic receptors caused by MBP $(n$ $=3$; mean $\pm \mathrm{SE} ; P$ $<0.01$, two-tailed unpaired Student's $t$ test). Guinea pig heart membranes were incubated with $\left[{ }^{3} \mathrm{H}\right]$ NMS $(1$ $\left.\times 10^{-10} \mathrm{M}\right)$ and $\mathrm{MBP}$ $\left(10^{-5} \mathrm{M}\right)$ for $3 \mathrm{~h}$. Hepa$\operatorname{rin}(100 \mathrm{U} / \mathrm{ml})$ or buffer was then added, and the mixture was incubated for an additional $3 \mathrm{~h}$ before filtration.

17), we postulated that MBP, or one of the other positively charged eosinophil proteins, might be responsible for the M2 receptor dysfunction (11). Consistent with this hypothesis is our finding that intravenous heparin or poly-l-glutamate, both of which bind and neutralize $\operatorname{MBP}(32,36)$, acutely restore the function of the pulmonary vagal M2 receptor in antigen-challenged guinea pigs (11). This recovery of $\mathrm{M} 2$ receptor function causes a $50 \%$ decrease in the bronchoconstrictor response to vagal stimulation within $20 \mathrm{~min}$ after administration of heparin or poly- $l$-glutamate. In contrast, neither heparin nor poly- $l$ glutamate affects the response to vagal stimulation in nonchallenged control guinea pigs. Thus the effect of MBP on M2 receptors may be physiologically relevant in the lungs.

This polyanion induced recovery of $\mathbf{M} 2$ receptor function is also reflected in the bronchoconstrictor response to vagal stimulation after treatment with muscarinic agonists and antagonists. In normal guinea pigs, stimulating $\mathrm{M} 2$ receptors with pilocarpine suppresses the bronchoconstrictor response to vagal stimulation. Conversely, blocking the M2 receptor with gallamine increases the bronchoconstrictor response to vagal stimulation. In contrast, the effects of both pilocarpine and gallamine on the response to vagal stimulation are markedly reduced in antigen-challenged guinea pigs. Treatment with heparin or poly-l-glutamate completely restores the effects of pilocarpine and gallamine, indicating return of $\mathrm{M} 2$ receptor function to normal (11).

Our finding in this study that MBP is a selective allosteric antagonist at the $\mathrm{M} 2$ receptor, and that binding of MBP to the M2 receptor can be reversed by heparin, is consistent with MBP being responsible for the loss of M2 receptor function in antigen-challenged guinea pigs. MBP might also be responsible for the $\mathrm{M} 2$ receptor dysfunction found in asthmatics $(8,9)$, as the airways of asthmatics are also infiltrated with eosinophils (12-15). As MBP is a selective M2 antagonist, it will increase acetylcholine release from pulmonary vagal fibers without blocking the $\mathrm{M} 3$ receptors that mediate the smooth muscle response to acetylcholine.

On a molar basis EPO, which is also cationic, is only slightly less potent than MBP as an M2 antagonist. However, EPO is present in much smaller molar amounts in the eosinophil granule than is MBP (Gleich, G. J., unpublished observations). Considering that EPO is less plentiful than MBP, and that it is also less potent as an M2 antagonist, the effects of EPO on M2 receptors may not be physiologically relevant.

While the actual concentration of MBP in the tissues is not known, the finding of micromolar amounts of MBP in the 
sputum of patients with acute asthma (37) suggests that tissue concentrations (which would probably be higher than sputum concentrations) are in the range that we have shown affects the M2 receptor. Thus, the ability of MBP to act as an endogenous antagonist of inhibitory muscarinic $\mathrm{M} 2$ receptors may be important in explaining the increased vagally mediated bronchoconstriction characteristic of asthma.

\section{Acknowledgments}

The authors thank Ms. Catherine Hassler King for technical assistance, and Mr. James L. Checkel and Mr. David A. Loegering for purification of eosinophil granules and eosinophil proteins.

This work was funded by National Institutes of Health grants HL47120 (Dr. Jacoby), HL-44727 (Dr. Fryer), and AI-09728 (Dr. Gleich), and by grants from the Tobacco Research Council (Dr. Fryer) and the American Lung Association (Dr. Fryer). Dr. Jacoby is a recipient of the Edward Livingston Trudeau Scholarship from the American Lung Association.

\section{References}

1. Roffel, A. F., W. G. in't Hout, R. A. de Zeeuw, and J. Zaagsma. 1987. The M2 selective antagonist AF-DX 116 shows high affinity for muscarine receptors in bovine tracheal membranes. Naunyn-Schmiedeberg's Arch. Pharmacol. 335:593-595.

2. Fryer, A. D., and E. E. El-Fakahany. 1990. Identification of three muscarinic receptor subtypes in rat lung using binding studies with selective antagonists. Life Sci. 47:611-618.

3. Mahesh, V. K., L. M. Nunan, M. Halonen, H. I. Yamamura, J. D. Palmer, and J. W. Bloom. 1992. A minority of muscarinic receptors mediate rabbit tracheal smooth muscle contraction. Am. J. Respir. Cell Mol. Biol. 6:279-286.

4. Fryer, A. D., and J. Maclagan. 1984. Muscarinic inhibitory receptors in pulmonary parasympathetic nerves in the guinea-pig. Br. J. Pharmacol. 83:973 978.

5. Blaber, L. C., A. D. Fryer, and J. Maclagan. 1985. Neuronal muscarinic receptors attenuate vagally-induced contraction of feline bronchial smooth muscle. Br. J. Pharmacol. 86:723-728.

6. Ito, Y., and T. Yoshitomi. 1988. Autoregulation of acetylcholine release from vagus nerves terminals through activation of muscarinic receptors in the dog trachea. Br. J. Pharmacol. 93:636-646.

7. Minette, P., and P. J. Barnes. 1988. Prejunctional inhibitory muscarinic receptors on cholinergic nerves in human and guinea-pig airways. J. Appl. Physiol. 64:2532-2537.

8. Ayala, L. E., and T. Ahmed. 1989. Is there loss of a protective muscarinic receptor in asthma? Chest. 96:1285-1291.

9. Minette, P. J., J. W. J. Lammers, C. M. S. Dixon, M. T. McCusker, and P. J. Barnes. 1989. A muscarinic agonist inhibits reflex bronchoconstriction in normal but not asthmatic subjects. J. Appl. Physiol. 67:2461-2465.

10. Fryer, A. D., and M. Wills-Karp. 1991. Dysfunction of M2 muscarinic receptors in pulmonary parasympathetic nerves after antigen challenge in guineapigs. J. Appl. Physiol. 71:2255-2261.

11. Fryer, A. D., and D. B. Jacoby. 1992. The function of pulmonary M2 muscarinic receptors in antigen challenged guinea-pigs is restored by heparin and poly-l-glutamate. J. Clin. Invest. 90:2292-2298.

12. Laitinen, L. A., M. Heino, A. Laitinen, T. Kava, and T. Haahtela. 1985 Damage of the airway epithelium and bronchial reactivity in patients with asthma. Am. Rev. Respir. Dis. 131:599-606.

13. Kay, A. B. 1992. "Helper" (CD4+) T cells and eosinophils in allergy and asthma. Am. Rev. Respir. Dis. 145:S22-S26.

14. Ohashi, Y., S. Motojima, T. Fukuda, and S. Makino. 1992. Airway hyperresponsiveness, increased intracellular spaces of bronchial epithelium, and increased infiltration of eosinophils and lymphocytes in bronchial mucosa in asthma. Am. Rev. Respir. Dis. 145:1469-1476.

15. Azzawi, M., P. W. Johnston, S. Majumdar, A. B. Kay, and P. K. Jeffery.
1992. T lymphocytes and activated eosinophils in airway mucosa in fatal asthma and cystic fibrosis. Am. Rev. Respir. Dis. 145:1477-1482.

16. Gulbenkian, A. R., X. Fernandez, W. Kreutner, M. Minnicozzi, A. S. Watnick, T. Kung, and R. W. Egan. 1990. Anaphylactic challenge causes eosino phil accumulation in bronchoalveolar lavage fluid of guinea pigs: modulation by betamethasone, phenidione, indomethacin, WEB 2086, and a novel antiallergy agent, SCH 37224. Am. Rev. Respir. Dis. 142:680-685.

17. Ishida, K., L. J. Kelly, R. J. Thomson, L. L. Beattie, and R. R. Schellenberg. 1989. Repeated antigen challenge induces airway hyperresponsiveness with tissue eosinophilia in guinea-pigs. J. Appl. Physiol. 67:1133-1139.

18. Ten, R. M., L. R. Pease, D. J. McKean, M. P. Bell, and G. J. Gleich. 1989. Molecular cloning of the human eosinophil peroxidase. Evidence for the existence of a peroxidase multigene family. J. Exp. Med. 169:1757-1769.

19. Barker, R. L., R. M. Ten, D. A. Loegering, K. J. Hamann, L. R. Pease, and G. J. Gleich. 1989. Eosinophil cationic protein cDNA. Comparison with other toxic cationic proteins and ribonucleases. J. Immunol. 143:952-955.

20. Hu, J., S.-Z. Wang, C. Forray, and E. E. El-Fakahany. 1992. Complex allosteric modulation of cardiac muscarinic receptors by protamine: a potential model for putative endogenous ligands. Mol. Pharmacol. 42:311-324.

21. Gies, J.-P., C. Bertrand, P. Vanderheyden, F. Waeldele, P. Dumont, G. Pauli, and Y. Landry. 1989. Characterization of muscarinic receptors in human, guinea pig and rat lung. J. Pharmacol. Exp. Ther. 250:309-315.

22. Peterson, G. L., L. C. Rosenbaum, D. J. Broderick, and M. I. Schimerlik. 1986. Physical properties of the purified cardiac muscarinic acetylcholine receptor. Biochemistry. 25:3189-3202.

23. Kubo, T., K. Sukuda, A. Mikami, A. Maeda, H. Takahashi, M. Mishina, T. Haga, K. Haga, A. Ichiyama, K. Kangawa, M. Kojima, H. Matsuo, T. Hirose, and S. Numa. 1988. Cloning, sequencing, and expression of complementary DNA encoding the muscarinic acetylcholine receptor. Nature (Lond.). 323:411416.

24. Ladinsky, H., E. Giraldo, E. Monferini, G. B. Schiavi, M. A. Vigano, L. DeConti, R. Micheletti, and R. Hammer. 1988. Muscarinic receptor heterogeneity in smooth muscle: binding and functional studies with AF-DX 116. Trends Pharmacol. Sci. 9(Suppl.):44-48.

25. Kromer, W., E. Baron, M. Beinborn, R. Boer, and M. Eltze. 1990. Characterization of the muscarine receptor type on paracrine cells activated by McN-A343 in the mouse isolated stomach. Naunyn-Schmiedeberg's Arch. Pharmacol. 341:165-170.

26. Gleich, G. J., D. A. Loegering, K. G. Mann, and J. E. Maldonado. 1976. Comparative properties of the Charcot-Leyden crystal protein and the major basic protein from human eosinophils. J. Clin. Invest. 57:633-640.

27. Slifman, N. R., D. A. Loegering, D. J. McKean, and G. J. Gleich. 1986. Ribonuclease activity associated with human eosinophil-derived neurotoxin and eosinophil cationic protein. J. Immunol. 137:2913-2917.

28. Limbird, L. E. 1986. Cell Surface Receptors: A Short Course on Theory and Methods. Martinus Nijhoff Publishing, Boston. 196 pp.

29. Lee, N. H., and E. E. El-Fakahany. 1991. Allosteric interactions at the $\mathrm{ml}$, $\mathrm{m} 2$ and $\mathrm{m} 3$ muscarinic receptor subtypes. J. Pharmacol. Exp. Ther. 256:468479.

30. Lee, N. H., and E. E. El-Fakahany. 1991. Allosteric antagonists of the muscarinic acetylcholine receptor. Biochem. Pharmacol. 42:199-205.

31. Michel, A. D., R. E. Delimendo, M. Lopez, and R. L. Whiting. 1990. On the interaction of gallamine with muscarinic receptor subtypes. Eur. J. Pharmacol. 182:335-345.

32. Frigas, E., D. A. Loegering, and G. J. Gleich. 1980. Cytotoxic effect of the guinea pig major basic protein on tracheal epithelium. Lab. Invest. 42:35-43.

33. Lee, N. H., J. Hu, and E. E. El-Fakahany. 1992. Modulation by certain conserved aspartate residues of the allosteric interaction of gallamine at the $\mathrm{ml}$ muscarinic receptor. J. Pharmacol. Exp. Ther. 262:312-316.

34. Cheng, J. B., and R. G. Townley. 1983. GTP increases airway muscarinic antagonist binding sites: an effect regulated by $\mathrm{Mg}^{++}$. Eur. J. Pharmacol. 88:269272.

35. McCaig, D. J. 1987. Comparison of autonomic responsies in the trachea isolated from normal and albumin-sensitive guinea-pigs. Br. J. Pharmacol. 92:809-816.

36. Barker, R. L., R. H. Grundel, G. J. Gleich, J. L. Checkel, D. A. Loegering, L. R. Pease, and K. J. Hamann. 1991. Acidic polyamino acids inhibit eosinophil granule major basic protein toxicity. J. Clin. Invest. 88:798-805.

37. Frigas, E., D. A. Loegering, G. O. Solley, G. M. Farrow, and G. J. Gleich. 1981. Elevated levels of the eosinophil granule MBP in the sputum of patients with bronchial asthma. Mayo Clin. Proc. 56:345-353. 